Marquette University

e-Publications@Marquette

College of Education Faculty Research and

Publications

Education, College of

4-1-2005

Entry-Level Competencies of New Student Affairs Professionals: A Delphi Study

\author{
Alan W. Burkard \\ Marquette University, alan.burkard@marquette.edu \\ Darnell Cole \\ University of Hawaii at Manoa \\ Molly Ott \\ University of Michigan \\ Tara Stoflet
}

Published version. NASPA Journal, Vol. 42, No. 3 (Spring 2005): 283-309. DOI. (C) 2005 NASPA. Used with permission. 


\title{
Entry-Level Competencies of New Student Affairs Professionals: A Delphi Study
}

\author{
Alan Burkard \\ Darnell C. Cole \\ Molly Ott \\ Tara Stoflet
}

The study examines the perceptions of 104 mid- and senior-level student affairs administrators of positions, responsibilities, competencies, and theories important for professional practice for new student affairs professionals. In regard to competencies, the results of this study provide important information about preprofessional abilities that are integral to professional practice, and participants also identified several competencies not identified in prior research that may be important to positions involving high contact with students. These results, then, provide vital information for curriculum development in graduate preparation programs and for professional development training for new professionals.

Alan Burkard is an assistant professor in the Department of Counseling and Educational Psychology at Marquette University; Darnell C. Cole is an associate professor in the Department of Educational Administration at the University of Hawaii-Manoa; Molly Ott is a doctoral student in the Higher Education program at the University of Michigan; and Tara Stoflet is a counselor in a community agency.

We thank all of the student affairs professionals who participated in this study. Additionally, we thank Dr. Sherri Crahen for her comments on an earlier draft of this article. Finally, we acknowledge that this research was funded through a research grant provided by Dr. Madeline Wake, Office of the Provost, Marquette University. 
In an examination of any given profession, one may ask, "What principles, knowledge, and skills provide the foundation for defining our profession?" This question has been an important area of query within student affairs (Lovell \& Kosten, 2000), and the focus of several empirical investigations. For example, studies have examined faculty and administrator perceptions of graduate school training in student affairs (Beatty \& Stamatakos, 1990), expectations regarding new professional competencies (Newton \& Richardson, 1976; Ostroth, 1981), perceived functions and responsibilities of middle-level student affairs administrators (Baier, 1992; Gordon, Strode, \& Mann, 1993), and college/university presidents' expectations of competencies among senior student affairs officials (Lunsford, 1984). Despite these investigations, Pope and Reynolds (1997) noted that the literature "reveals no consensus about core competencies for students affairs practitioners" (p. 268), a perspective recently echoed by Herdlein (2004) and Lovell and Kosten (2000).

This study, then, attempted to build consensus among a panel of student affairs experts regarding important responsibilities, skills, and theoretical knowledge bases that may be important to entry-level student personnel work. The outcomes of this investigation may be important to those individuals who educate, mentor, or supervise individuals either entering the profession; or to those individuals who may be looking to increase their competencies through continuing education or staff development activities. Additionally, those who seek to recruit and hire such professionals may find the results of this study useful in identifying skills and competencies important to entry-level professionals. Finally, researchers who study the professional competencies of student affairs may also find the results of this investigation useful in extending their own work. Prior to presenting the results of this investigation, a brief overview of the exact research on entry-level competencies in student affairs will be presented.

\section{Empirical Studies}

Surprisingly little research has focused on this gap in the research, the skills, competencies, or knowledge bases important to entry-level student affairs professionals. For example, Lovell and Kosten (2000) recently conducted a comprehensive meta-analysis of 30-years of 
research on skills, knowledge, and personal traits of student affairs administrators; and were able to identify two investigations relevant to entry-level professionals (i.e., Newton \& Richardson, 1976; Ostroth, 1981). Although the findings from these two studies are over 2 decades old, they do offer some initial insights into competencies believed to be important at that time. Participants in both studies identified the importance of human relations skills; and they specifically identified interpersonal relations, individual and group counseling, the ability to work with students, and the recognition of and services to ethnic minority students. In addition to skills related to direct student contact, participants from both the Newton and Richardson (1976) and Ostroth (1981) studies also reported that management skills were important to entry-level practice. Here, participants identified leadership and understanding, organizing, and administering student personnel programs as essential skills for practioners.

In a recent study not included in Lovell and Kosten's (2000) metaanalysis, Herdlein (2004) surveyed 50 chief student affairs officers' perceptions regarding the relevance of graduate preparation for new professionals. In relation to skills participants perceived as essential to student affairs practice, participants endorsed management skills most frequently, particularly those skills of budgeting, collaboration, leadership, and writing abilities. Human relations skills were the second most frequently endorsed competencies; and participants specifically identified work with diverse populations, communication, interpersonal skills, empathy and firmness, and caring. Finally, participants also identified several personal attributes as important for successful practice, with flexibility, critical thinking, work ethic, values, problem solving, and maturity most frequently cited.

Although the information garnered from the Newton and Richardson (1976) and Ostroth (1981) studies provides valuable insights into skills identified as important to student affairs, colleges and universities have significantly changed since the late 1970s and early 1980s. For example, technology has influenced campus life, often transforming how students, staff, and faculty communicate, interact, and even learn (Barrett, 2003). Although skills relevant to technology did not emerge as important in Herdlein's (2004) recent study, his findings did support the continued importance of human relations and management skills. In addition to these identified areas of competence, all 
three studies found multicultural sensitivity as important to student affairs practice. Colleges and universities have sought to increase the diversity of the academic environment, and they have specifically sought to meet the needs of culturally diverse groups through programming and outreach on campus (Jones, Castellanos, \& Cole, 2002; Talbot, 2003). As a result, multicultural affairs offices and gay, lesbian, bisexual services have emerged to address the needs of culturally diverse students (El-Khawas, 2003).

Finally, legal issues, ethical standards, and ethical decision-making models have progressively been emphasized in student affairs practice (Fried, 2003), although these areas of practice did not emerge as important in prior investigations (Herdlein, 2004; Newton \& Richardson, 1976; Ostroth, 1981). These recent developments in student affairs practice may have influenced common knowledge about the professional practice of student affairs, and competency is conceptualized in the profession.

\section{Purpose of Study}

No one may be better positioned to help us understand the necessary entry-level competencies of a student affairs professional than those individuals who recruit, select, hire, and supervise such staff members. This study, then, sought to build consensus among mid- and senior-level student affairs administrators regarding entry-level student affairs positions, responsibilities, skills, and theoretical knowledge bases. The Delphi method was used in this study for two reasons. First, as a research method it was designed to help bring clarity to a complex area in need of structure (Linstone \& Turoff, 1975). Second, the Delphi method uses surveys to build consensus among a panel of experts about an area of inquiry. As such, this technique relies on multiple iterations of and responses to a survey by a single sample of experts. Delphi surveys are time efficient and provide a means of gathering consensus among experts without physically having the experts meet. Additionally, the Delphi technique has consistently resulted in clearer and more comprehensive information regarding studied areas than individual experts alone (Ascher, 1978; Linstone \& Turoff, 1975). Finally, the Delphi method provides another advantage in that it "attempts to negotiate a reality that can then be useful in moving a 
particular field forward, planning for the future, or even changing the future by forecasting its events" (Fish \& Busby, 1996, p. 470).

\section{Method}

\section{The Expert Panel/Participants}

Selection of the panel of experts (i.e., participants) is a critical aspect of the Delphi method. The panel's knowledge of the area of study is essential to the integrity and quality of the outcome of the investigation (Dalkey, 1969). While the field of postsecondary educational administrators includes over 98,000 people (Bureau of Labor Statistics, 2004), this investigation randomly selected 300 middle- to senior-level student affairs administrators from over 8,500 members of National Association of Student Personnel Administrators (NASPA) to participate in this study. Participants were included as panelists if they met two criteria: (1) had active membership in NASPA and (2) were minimally in an assistant director's position within student affairs. One-hundred-and-four participants completed all three iterations of the Delphi survey, resulting in a final response rate of $35 \%$.

Participants consisted of 104 practicing student affairs professionals in middle- to senior-level positions who were members of NASPA. Participants were between the ages of 25 to $64(M=40.21 ; S D=9.82)$, and 65 were women and 39 were men. Participants had practiced in student affairs between 2 to 37 years $(M=14.63 ; S D=9.00)$ and had been in their current position between 1 to 24 years $(M=5.31 ; S D=$ 5.05). The sample consisted of 4 African Americans, 5 Asian Americans, 88 European Americans, 6 Latinas/Latinos, and 1 individual who identified as Biracial. Sixty-four participants indicated having a master's degree, 3 had a BA/BS, 27 had an Ed.D./Ph.D., and data were missing on the educational level for 10 respondents. The largest numbers of respondents were from 4-year public institutions $(N=64)$, the next largest group was from 4-year private institutions $(N=36)$, and the smallest group was from 2-year community colleges $(N=4)$. In regard to the size of the institution, 24 respondents were from institutions larger than 25,$000 ; 25$ were from institutions of 15,000 to 24,999 ; 16 were from institutions of 10,000 to 14,999 ; 14 were from institutions of 5000 to 9999 ; and 25 were from institutions with 4,999 or less students. 


\section{Measures and Procedures}

An iterative series of three questionnaires were distributed to a national sample of 300 student affairs administrators between September 2003 and June 2004. The first iteration included a letter of introduction, instructions for participation, and a letter of informed consent.

In the first iteration, participants were presented with open-ended questions as recommended by Delphi methodologists (Ascher, 1978; Dalkey, 1969; Fish \& Busby, 1996; Linstone \& Turoff, 1975). Participants were asked to provide written responses to four areas: (1) typical entry-level positions in student affairs, (2) responsibilities common to these positions, (3) skills necessary to be effective in the identified positions and in completing the responsibilities, and (4) theoretical foundations that are important to student affairs practice. In the first survey round, participants provided responses without knowledge of their peers' responses. The response rate for this iteration was $36 \%(N=108)$.

In the second iteration, participants were provided with feedback from the first iteration. Prior to the distribution of the second iteration, the written data from the first survey was transcribed; and the first, third, and fourth authors identified the themes from the transcribed data. Based on the four open-ended questions, the research team developed an initial "start list" (Miles \& Huberman, 1994) of themes (i.e., topic areas). These themes helped the team to cluster the data about similar topic areas. Each team member independently reviewed and assigned data to the themes, and all data were assigned to at least one theme. After this independent review, the team met to compare and discuss their assignment of data to themes until they came to consensus regarding the appropriate assignment of all data. A theme was retained for item development if a minimum of five participants endorsed the theme.

After consensus had been reached for the theme, each team member independently read all of the data and identified the "core ideas" within each theme. The process of identifying core ideas is often called "boiling down" or "abstracting" (Strauss \& Corbin, 1990); and the goal of this process is to reduce the data to more concise and essential terms, with core ideas that closely reflect the raw data. After the team 
members' independent creation of core ideas for each case, the research team met and discussed the core ideas until the group arrived at consensus regarding their content and wording. The team also converted the core ideas into survey items that would be used in the second and third iteration of the Delphi procedure. This review process resulted in a consensus version that contained the transcribed data, which had been coded into themes, and the corresponding core ideas/survey items.

The consensus version was then sent to the auditor (i.e., second author) for independent review. The auditor's role here is to check the assignment of interview data to themes, and to scrutinize the accuracy of each core idea. The auditor provided feedback to the research team, and again the team reviewed and discussed auditor comments/feedback until consensus was reached regarding changes to the domain coding and/or the wording of core ideas and survey items. This process resulted in the development of the second survey. The questionnaire was comprised of four sections: typical entry-level positions (27 items), typical responsibilities of entry-level student affairs positions (26 items), skills necessary to complete identified responsibilities (32 items), and theoretical foundations that serve as foundation for student affairs practice (16 items). In the second iteration of the survey, participants were asked to rate the importance of each survey item on a 7 -point, Likert-type scale where 1 = strongly disagree, 4 $=$ neutral, and 7 = strongly agreed, again without knowledge of their peers' ratings. A demographic questionnaire was also included in this round of the survey.

In the third and final iteration, participants were provided with aggregate group responses from the second iteration. These aggregate responses consisted of mean responses for each item listed in the second iteration. Participants were asked to review the mean responses from the second iteration, consider their own responses from the second iteration, and make new ratings for only those items they wished to change and identify as more or less important for entry-level positions in student affairs. The ratings from this final iteration were then averaged to arrive at the final ratings of importance for each item. 


\section{Results}

As a context for the following results, we wanted to determine if type of institution (i.e., 2-year and 4-year institutions, and private and public institutions), and size of the institution was a factor in which positions, responsibilities, and skills were reported as important to entrylevel positions in student affairs. A series of analysis of variance (ANOVA) was computed for each of the identified responsibilities and skills. None of these analyses emerged as significant, so the proceeding results appear representative of many different types and sizes of institutions.

\section{Entry-Level Positions}

Each of the experts identified up to 10 student affairs positions he/she believed to represent typical entry-level jobs. As presented in Table 1, the experts identified 27 different entry-level positions in student affairs. Perhaps not surprisingly, participants reported positions that typically involve high student contact through direct individual or group services (e.g., admissions counselor, residence hall director, student organization advisor), and these types of positions were often ranked high in their representation of typical entry-level positions. In addition to direct student contact, several positions also appear responsible for program development activity and conceptualization of direct services. Here, for example, intramural athletics coordinator, student life coordinator, and assistant director of student activities are representative of such positions. And finally, a few positions (e.g., director of orientation, director of student activities, campus center/union director) appeared to have more direct administrative/management responsibilities, and possibly more direct staff supervision responsibilities. These positions were low in frequency and ranked low in importance as an entry-level position in student affairs.

\section{Responsibilities}

As displayed in Table 2, our experts identified 26 responsibilities typical to entry-level student affairs positions. Respondents overwhelmingly identified responsibilities that were directly related to providing direct services to students. In fact, over half of the 26 responsibilities corresponded to student contact (e.g., present/facilitate programs for 
Table 1

Typical Entry-Level Positions in Student Affairs in Rank Order

\begin{tabular}{|c|c|c|c|c|c|c|}
\hline \multicolumn{2}{|c|}{ Entry-Level Positions } & \multicolumn{2}{|c|}{ Round 1} & \multicolumn{2}{|c|}{ Round 2} & \multirow[t]{2}{*}{ Rank } \\
\hline & & $M$ & $S D$ & $M$ & So & \\
\hline 1. & Admissions Counselor (e.g., Recruiter) & 6.55 & 80 & 6.49 & .71 & 1 \\
\hline 2. & Residence Hall Director & 5.95 & $\$ .75$ & 5.94 & .84 & 2 \\
\hline 3. & $\begin{array}{l}\text { Student Organization Advisor (e.g., } \\
\text { Student Goverument Advisor) }\end{array}$ & 5.94 & 1.18 & 5.93 & .75 & 3 \\
\hline 4. & Intramural Athletics Coordinator & 5.76 & 1.38 & 5.85 & .62 & 4 \\
\hline 5. & Financial Aid Advisor (e,g, Counselor) & $\$ .44$ & 1.45 & 5.45 & .63 & 5 \\
\hline 6. & Recreation Center Coordinator & 5.34 & 1.49 & 5.44 & .56 & 6 \\
\hline 7. & Career Services Counselor & $\$ .49$ & 1.36 & 5.44 & .61 & 6 \\
\hline 8. & First Year Experience Advisor & 5.32 & 1.17 & 5.35 & .80 & 7 \\
\hline 9. & Greek Life Coordinator (e.g., Advisor) & 5.41 & 1.33 & 5.32 & .75 & 8 \\
\hline 10 & $\begin{array}{l}\text { Health Educator (includes Wellness } \\
\text { Coordinator) }\end{array}$ & 5.17 & 1.40 & 5.27 & .61 & 9 \\
\hline 11. & Academic Advisor & 5.25 & 1.40 & 5.23 & .62 & 10 \\
\hline 12. & Service Learning Coordinator & 5.04 & 1.41 & 5.13 & .66 & 11 \\
\hline 13. & Leadership Coordinator & 4.94 & 1.48 & 4.99 & .63 & 12 \\
\hline 14. & Student Life Coordinator & 4.75 & 1.57 & 4.89 & .68 & 13 \\
\hline 15 & Assistant Director of Orientation & 4.68 & 1.53 & 4.55 & .78 & 14 \\
\hline 16 & Student Development Specialist & 4.51 & 1.48 & 4.47 & .70 & 15 \\
\hline 17 & Assistant Director of Student Activities & 4.53 & 1.77 & 4.41 & .87 & 16 \\
\hline 18. & Career Services Coordinator & 4.25 & 1.66 & 4.20 & .85 & 17 \\
\hline 19. & $\begin{array}{l}\text { Assistant Director of International } \\
\text { Services (e.g., House) }\end{array}$ & 4.22 & 1.45 & 4.19 & .69 & 18 \\
\hline 20. & $\begin{array}{l}\text { Coordinator of Lesbian, Bisexual, Gay } \\
\text { and Transgender Services }\end{array}$ & 4.24 & 1.47 & 4.17 & .95 & 19 \\
\hline 21 & Judicial Officer & 3.92 & 1.64 & 4.04 & .95 & 20 \\
\hline 22. & Coordinator of Multicultural Affairs & 4.04 & 1.65 & 3.95 & .95 & 21 \\
\hline 23. & Counseling Center Coutselor & 3.71 & 1.93 & 3.54 & 1.02 & 22 \\
\hline 24. & $\begin{array}{l}\text { Assistant Director of Residence } \\
\text { Life/Housing }\end{array}$ & 3.68 & 1.69 & 3.35 & 1.10 & 23 \\
\hline 25. & Director of Orientation & 2.34 & 1.48 & 2.30 & .81 & 24 \\
\hline 26. & Director of Student Activities & 2.25 & 1.38 & 2.18 & .83 & 25 \\
\hline 27. & Campus Center (Union) Director & 1.90 & 1.23 & 1.95 & .75 & 26 \\
\hline
\end{tabular}


Table 2

\section{Common Position Responsibilities for Entry-Level Positions in Student Affairs in Rank Order}

\begin{tabular}{|c|c|c|c|c|c|}
\hline Responsibilities & \multicolumn{2}{|c|}{ Round 1} & \multicolumn{2}{|c|}{ Round 2} & \multirow[t]{2}{*}{ Rank } \\
\hline & $M$ & $S D$ & $M$ & $S D$ & \\
\hline 1. Present/facilitate programs for students ${ }^{\mathrm{a}}$ & 6.33 & .91 & 6.39 & .26 & 1 \\
\hline 2. Advise student groups & 6.27 & .99 & 6.33 & .31 & 2 \\
\hline $\begin{array}{l}\text { 3. Plan, coordinate and oversec student } \\
\text { programming }\end{array}$ & 6.22 & 1.08 & 6.29 & .29 & 3 \\
\hline 4. Advisc individual students & 6.21 & .92 & 6.22 & .42 & 4 \\
\hline 5. Be a problem-solver ${ }^{a}$ & 6.21 & .84 & 6.21 & .43 & 5 \\
\hline 6. Mentor student leaders & 6.08 & .89 & 6.16 & .48 & 6 \\
\hline 7. Supervise student employees ${ }^{3}$ & 5.80 & 1.13 & 5.81 & .49 & 7 \\
\hline $\begin{array}{l}\text { 8. Interpret and enforce university policies } \\
\text { and regulations }{ }^{a}\end{array}$ & 5,81 & 1.17 & 5.81 & .66 & 7 \\
\hline 9. Promote university events $c$ & 5.58 & 1.25 & 5.72 & .52 & 8 \\
\hline $\begin{array}{l}\text { 10. Develop and provide training for student } \\
\text { employees }\end{array}$ & 5.57 & 1.24 & 5.65 & .35 & 9 \\
\hline 11. Supervise student paraprofessional staff ${ }^{a}$ & 5.60 & 1,26 & 5.61 & .67 & 10 \\
\hline $\begin{array}{l}\text { 12. Collaborate with other } \\
\text { departmetits/offices regarding campus } \\
\text { services/programming }\end{array}$ & 5.50 & 1.21 & 5.59 & .44 & 11 \\
\hline $\begin{array}{l}\text { 13. Facilitate leadership development } \\
\text { training/workshops }\end{array}$ & 5.49 & 1.09 & 5.56 & .49 & 12 \\
\hline 14. Serve as a university representative ${ }^{\mathrm{e}}$ & 5.50 & 1.34 & 5.51 & .61 & 13 \\
\hline 15. Provide evaluation of programming & 5.50 & 1.34 & 5.48 & .50 & 14 \\
\hline 16. Participate in staff selection ${ }^{\mathrm{c}}$ & 5.44 & 1.27 & $\$ .45$ & .56 & 15 \\
\hline 17. Write reports ${ }^{c}$ & 5.42 & 1.38 & 5.38 & .80 & 16 \\
\hline $\begin{array}{l}\text { 18. Serve on department and university } \\
\text { committees }\end{array}$ & 5.39 & 1.33 & 5.31 & .75 & 17 \\
\hline $\begin{array}{l}\text { 19. Develop and provide training for } \\
\text { paraprofessional staff }\end{array}$ & 5.33 & 1.33 & 5.29 & .77 & 18 \\
\hline 20. Facilitate conflici mediation ${ }^{a}$ & $\$ .22$ & 1.36 & 5.25 & .60 & 19 \\
\hline $\begin{array}{l}\text { 21. Recruitnsent of students to the } \\
\text { university" }\end{array}$ & 4.95 & 1.52 & 5.11 & .72 & 20 \\
\hline 22. Provide crisis intervention ${ }^{a}$ & 4.81 & 1.51 & 4.80 & .75 & 21 \\
\hline $\begin{array}{l}\text { 23. Provide counsoling to individual } \\
\text { students }\end{array}$ & 4.72 & 1.53 & 4.78 & .86 & 22 \\
\hline $\begin{array}{l}\text { 24. Provide consultation to parents, faculty } \\
\text { and/cr other university staff }\end{array}$ & 4.67 & 1.37 & 4.63 & .91 & 23 \\
\hline 25. Maintain website/database & 4.16 & 1.61 & 4.26 & .79 & 24 \\
\hline 26. Develop and maintain a budget ${ }^{c}$ & 4.20 & 1.56 & 4.22 & .76 & 25 \\
\hline
\end{tabular}

${ }^{a}$ Direct student services. ${ }^{b}$ Program development. ${ }^{c}$ Administrative/management. $d_{\text {Research. }}{ }$ University representative. $\mathrm{f}_{\text {Technology. }}$ 
students; advise individual or groups of students; provide crisis intervention, counseling, or consultation) or providing support for student development (e.g., develop and provide training for student employees, facilitate leadership development training/workshops, mentor student leaders, supervise student staff or paraprofessionals). The second most frequently identified responsibilities were related to administrative/management responsibilities and included items such as participating in staff selection, writing reports, serving on university committees, and developing and maintaining a budget. Two items referred directly to officially representing the university, either as a university representative or in the recruitment of new students to the university. Finally, two single items corresponded to technology and research. Here participants reported that maintaining a Web site or database may be an important responsibility, and another item indicated that evaluating programming was an important responsibility to an entrylevel student affairs position.

\section{Competencies}

As Table 3 shows, experts identified 32 competencies as essential to entry-level positions in student affairs. Two competency areas emerged as particularly important: personal qualities and human relations skills. The personal qualities appear to be unique individual characteristics, which included flexibility, interpersonal relations, time management, managing multiple tasks, oral and written communication, problem-solving abilities, critical thinking, creativity, assertiveness, and analytical abilities. Interestingly, the top seven competencies identified by our respondents as important to entry-level positions in student affairs were personal qualities. Human relation skills were the second most important area of competency for entry-level positions. In this category of abilities respondents identified collaboration, teamwork/building, counseling, multicultural competency, training students/staff, presentation and group facilitation skills, advising, conflict resolution/mediation, supervision, crisis intervention, and consultation abilities.

Three other categories of competencies emerged as important to entrylevel positions in student affairs, but these areas appeared to be narrow in focus. For example, respondents identified administrative and management competencies, specifically identifying program develop- 
NASPA Journal, Vol. 42, no. 3

Table 3

Expected Competencies for Entry-Level Positions in Student Affairs in Rank Order

\begin{tabular}{|c|c|c|c|c|c|}
\hline Competencies & \multicolumn{2}{|c|}{ Round 1} & \multicolumn{2}{|c|}{ Round 2} & \multirow[t]{2}{*}{ Rank } \\
\hline & $M$ & $S D$ & $M$ & $S D$ & \\
\hline 1. Flexibility ${ }^{b}$ & 6.33 & .79 & 6.44 & .37 & I \\
\hline 2. Interpersonal relations ${ }^{b}$ & 6.37 & .71 & 6.42 & .34 & 2 \\
\hline 3. Time management & 6.34 & .69 & 6.41 & .35 & 3 \\
\hline $\begin{array}{l}\text { 4. Ability to manage multiple tasks (i.e., } \\
\text { multitasking) }\end{array}$ & 6.34 & .78 & 6.38 & .40 & 4 \\
\hline 5. Oral communication & 6.25 & .68 & 6.30 & .37 & 5 \\
\hline 6. Writen communication" & 6.14 & .97 & 6.22 & .44 & 6 \\
\hline 7. Problem-solving & 6.12 & .75 & 6.20 & .46 & 7 \\
\hline 8. Prograrn development/planning ${ }^{c}$ & 6.15 & .96 & 6.20 & .47 & 7 \\
\hline 9. Collaboration ${ }^{\mathrm{a}}$ & 6.11 & .86 & 6.18 & .44 & 8 \\
\hline 10. Teamwork/building ${ }^{a}$ & 6.05 & .84 & 6.13 & .44 & 9 \\
\hline 11. Counseling/active listening ${ }^{a}$ & 6.00 & .99 & 6.08 & .46 & 10 \\
\hline 12. Multicultural competency ${ }^{a}$ & 6.02 & .99 & 6.04 & .48 & 11 \\
\hline 13. Grganizational skills ${ }^{\mathrm{c}}$ & 5.90 & .89 & 6.03 & .50 & 12 \\
\hline 14. Critical thinking ${ }^{b}$ & 5.88 & .92 & 5.99 & .46 & 13 \\
\hline $\begin{array}{l}\text { 15. Develop and present training for } \\
\text { students/staff }\end{array}$ & 5.73 & .98 & 5.83 & .40 & 14 \\
\hline 16. Leadership ${ }^{c}$ & 5.77 & .98 & 5.87 & .43 & 15 \\
\hline 17. Presentation skiliş ${ }^{\mathrm{a}}$ & 5.81 & 1.02 & 5.87 & .55 & 15 \\
\hline 18. Advising ${ }^{a}$ & 5.88 & .98 & 5.79 & .71 & 16 \\
\hline 19. Goab-seting ${ }^{\mathrm{C}}$ & 5.65 & .99 & 5.73 & .69 & 17 \\
\hline 20. Creativity & 5.62 & 1.13 & 5.69 & .54 & 18 \\
\hline 21. Group facilitation ${ }^{a}$ & 5.52 & 1.03 & 5.62 & .49 & 19 \\
\hline 22. Conflict resolution/mediation ${ }^{a}$ & 5.38 & 1.09 & 5.47 & .54 & 20 \\
\hline 23. Assertiveness/confromation ${ }^{b}$ & 5.23 & 1.22 & 5.40 & .58 & 21 \\
\hline 24. Computer/technology & 5.25 & 1.26 & 5.37 & .55 & 22 \\
\hline 25. Program evaluation ${ }^{\mathrm{d}}$ & 5.22 & 1.26 & 5.24 & .61 & 23 \\
\hline 26. Supervision ${ }^{\mathrm{a}}$ & 5.04 & 1.42 & 5.02 & .65 & 24 \\
\hline 27. Crisis interyention ${ }^{a}$ & 4.98 & $1.3 !$ & 5,01 & .78 & 25 \\
\hline 28. Administrative/management ${ }^{c}$ & 4.92 & 1.47 & 4.88 & .70 & 26 \\
\hline 29. Consultation ${ }^{2}$ & 4.77 & 1.40 & 4.79 & .67 & 27 \\
\hline 30. Analytical ${ }^{b}$ & 4.79 & 1.45 & 4.78 & .72 & 28 \\
\hline 31. Budgeting ${ }^{c}$ & 4.42 & 1.48 & 4,42 & .80 & 29 \\
\hline 32. Research & 3.70 & 1.56 & 3.72 & .84 & 30 \\
\hline
\end{tabular}

a Human relations skills. ${ }^{\mathrm{b}}$ Personal/preprofessional qualities. ${ }^{\mathrm{c}}$ Administrative/management. ${ }^{\mathrm{d}}$ Research. ${ }^{\mathrm{e}}$ Technology. 
ment and planning, organizational skills, leadership, goal-setting, management of budgets, and general administrative/management skills. Respondents also identified research (i.e., program evaluation, general research) and technology (i.e., computer/technology) skills as important to entry-level positions.

\section{Theories}

Finally, our experts were asked to identify theories they expected entry-level professionals to base their practice upon, and these results yielded 15 different theories that are presented in Table 4. Ten of the 15 theories were directly related to aspects of student development and included such theories as Astin's (1993) Theory of Student Involvement, the Seven Vectors of Student Development (Chickering \& Reisser, 1993), and Kohlberg's (1984) Moral Development model. The second category of theories were related to multicultural and diversity development models: for example, women's development (Gilligan, 1982); racial identity development (Cross, 1971, 1995; Helms, 1995); minority identity development (Atkinson, Morten, \& Sue, 1989); and lesbian, gay, and bisexual development (Cass, 1979; McCarn \& Fassinger, 1996). The final category of theories included broader psychological theories: Erikson's (1968) model of psychosocial development and Maslow's (1968) hierarchy of needs.

\section{Discussion}

\section{Positions and Corresponding Responsibilities}

To provide context for understanding the specific competencies identified as important for entry-level student affairs professionals, participants reported their perceptions of typical entry-level positions and corresponding responsibilities. Parallel to Kretovics' (2002) findings, our respondents typically identified entry-level positions that involved high student contact and program development and implementation. Respondents also emphasized a broad range of job responsibilities that corresponded with providing direct student assistance, including advising, mentoring, counseling, supervision, presenting or facilitating programs, mediating conflicts, and intervening in crisis situations. As such, these types of positions and responsibilities may have important implications for expected entry-level competencies. For example, 
Table 4

Theories Important to Entry-Level Practice in Student Affairs in Rank Order

\begin{tabular}{|c|c|c|c|c|c|}
\hline Theories & \multicolumn{2}{|c|}{ Round 1} & \multicolumn{2}{|c|}{ Round 2} & \multirow[t]{2}{*}{ Rank } \\
\hline & $M$ & $S D$ & $M$ & $S D$ & \\
\hline $\begin{array}{l}\text { 1. Theory of Student Involvement } \\
\text { (Astin, 1993) }\end{array}$ & 6.21 & 1.03 & 6.24 & .38 & 1 \\
\hline $\begin{array}{l}\text { 2. The Seven Vectors (Chickering \& } \\
\text { Reisser, 1993) }\end{array}$ & 6.03 & 1.24 & 6.12 & .37 & 2 \\
\hline $\begin{array}{l}\text { 3. Moral Development (Kohlberg, } \\
1984 \text { ) }\end{array}$ & 5.95 & .95 & 5.96 & .37 & 3 \\
\hline $\begin{array}{l}\text { 4. Cognitive and Ethical Growth } \\
\text { (Perry, 1981) }\end{array}$ & 5.78 & 1.16 & 5.81 & .43 & 4 \\
\hline $\begin{array}{l}\text { 5. Theory of Support and Challenge } \\
\text { (Sanford, 1967) }\end{array}$ & 5.55 & 1.53 & 5.71 & .58 & 5 \\
\hline $\begin{array}{l}\text { 6. Psychosocial development (Erikson, } \\
\text { 1968) }\end{array}$ & 5.67 & 1.19 & 5.61 & .62 & 7 \\
\hline 7. Hierarchy of Needs (Mastow, 1968) & 5.61 & 1.46 & 5.65 & .55 & 8 \\
\hline $\begin{array}{l}\text { 8. Women's Development (Gilligan, } \\
\text { 1982) }\end{array}$ & 5.39 & 1.41 & 5.41 & .46 & 9 \\
\hline $\begin{array}{l}\text { 9. Racial Identity Development Theory } \\
\text { (Cross, 1971, 1995; Helms, 1995) }\end{array}$ & 5.35 & 1.37 & 5.37 & .67 & 10 \\
\hline 10. Learning Style Theory (Kolb, 1984) & 5.32 & 1.39 & 5.28 & .72 & 11 \\
\hline $\begin{array}{l}\text { 11. Mattering and Marginality: } \\
\text { Transition Theory (Schlossberg, } \\
\text { 1989) }\end{array}$ & 4.82 & 1.49 & 4.90 & .64 & 12 \\
\hline $\begin{array}{l}\text { 12. Minority Identity Development } \\
\text { Model (Atkinson, Morten, \& Sue, } \\
\text { 1989) }\end{array}$ & 4.74 & 1.24 & 4.89 & .64 & 13 \\
\hline $\begin{array}{l}\text { 13. Reflective Judgment Model } \\
\text { (Kitchener \& King, 1990) }\end{array}$ & 4.68 & 1.31 & 4.79 & .47 & 14 \\
\hline $\begin{array}{l}\text { 14. Lesbian, Gay, Bisexual } \\
\text { Development (Cass, 1979; McCarn } \\
\text { \& Fassinger, 1996) }\end{array}$ & 4.67 & 1.41 & 4.78 & .51 & 15 \\
\hline $\begin{array}{l}\text { 15. Epistemological Reflection (Baxter } \\
\text { Magolda, 1992) }\end{array}$ & 4.12 & 1.51 & 4.11 & .51 & 16 \\
\hline
\end{tabular}


it would seem reasonable to assume that human relations and helping/counseling skills may be particularly important competencies for entry-level positions based on these findings.

To a lesser extent than direct student services, respondents also identified positions and responsibilities that emphasized administration and management of student services and programs. Responsibilities that may be reflective of this administrative and management focus would include staff selection, writing reports, departmental/university committee work, and budget development and maintenance. Positions and responsibilities in student affairs that emphasize direct student service and have some focus on management/administrative responsibilities appear consistent with prior research examining entrylevel positions (Kretovics, 2002; Newton \& Richardson, 1976; Ostroth, 1981).

Finally, the responsibilities for program evaluation, work with technology, and representing the university also were identified as important to entry-level positions in student affairs; but here again, these responsibilities were of lesser importance than direct services to students or program development. The integration of technology in student affairs represents a relatively important trend on campus (Barrett, 2003), and student affairs professionals are increasingly responsible for using technology to provide information and services to students. Additionally, the ability to conduct applied research in the form of program evaluation is becoming increasingly important as student affairs professionals are required to provide evidence that demonstrates the effectiveness of their programs (Upcraft, 2003). The inclusion of technology and program evaluation responsibilities may not be surprising, for theorists have noted these changes (Herdlein, 2004; Lovell \& Kosten, 2000). However, serving as a university representative appears to be a new responsibility not noted in prior research. Perhaps this finding is a result of the expanding roles of student affairs professionals, particularly as institutions face financial concerns and constraints.

\section{Entry-Level Competencies}

The competencies identified by the respondents in this survey provide information of foundational skills essential to effective entry-level stu- 
dent affairs practice. The collective findings suggest that human relations, administrative/management, technology, and research competencies-as well as several personal attributes-are important for successful entry-level practice. These competencies appear to directly correspond to the positions and responsibilities previously identified for entry-level professionals. As noted by Lovell and Kosten (2000), many of the identified competencies have been in demand for the past 30 years; however, the results of this study identified competencies not found in prior investigations. Consequently, these findings have important implications for training and assessment of new professionals. Perhaps the level of specificity that emerged from this investigation is a reflection of changing practices in student affairs and more recent changes in expectations of new professionals. Alternatively, it may also be that these current findings are a reflection of a field that is maturing in its conceptualization of what is defined as the professional practice of student affairs. In the following discussion, we will elaborate on our results and then address the potential implications of these findings for graduate training programs.

The administrators who participated in this study expect new professionals to have counseling skills that extend well beyond the basic skills often taught in graduate programs. For example, the skills typically taught in an introductory counseling course in graduate preparation programs focuses on individual approaches to counseling. On the other hand, collaboration, consultation, multicultural competency, group facilitation, conflict resolution/mediation, supervision, and crisis intervention represent advanced counseling/human relations competencies not generally addressed in graduate training (Lovell \& Kosten, 2000), but which are directly tied to the responsibilities identified by the participants (see Table 2). These advanced counseling/human relations competencies represent a significant change in expectations of new professionals, for prior research has not generally yielded the number of specific counseling/human relations skills that were identified in this investigation (i.e., Herdlein, 2004; Kretovics, 2002; Lovell \& Kosten, 2000; Newton \& Richardson, 1976; Ostroth, 1981). Perhaps these results are a reflection of the changing needs of students or the increasing demands on student affairs professionals in a competitive postsecondary education environment. These skills are, however, consistent with the recommended curriculum standards of Council for the Advancement of Standards in 
Higher Education (CAS, 2003) for Professional Studies, and more specifically the standards related to Individual, Group, and Organizational Interventions. From the respondents' perspective, new professionals should have advanced counseling/human relation skills that extend well beyond the basic counseling competencies acquired during their graduate training.

It also appears clear from our findings that successful entry-level student affairs professionals have a number of personal attributes and preprofessional abilities. In fact, a combination of these qualities emerged as the top seven competencies important for success as entrylevel student affairs professionals. For example, personal qualities such as flexibility, interpersonal relations, analytical, critical thinking, problem-solving, creativity, and assertiveness emerged as important; and preprofessional skills like time management, multitasking, and oral/written communication were also identified by respondents. Collectively these abilities may be important to student affairs professionals, for they appear to be qualities that would allow for a new professional to quickly adapt to and make decisions in a rapidly changing environment. Perhaps these personal attributes and preprofessional abilities represent dispositions that are essential to and underlie successful student affairs practice and may have important implications for training. For example, Herdlein (2004) noted that new professionals' proficiency in writing skills was a shortcoming in their preparation, perhaps an indication that writing skills in particular need further development prior to or during graduate training. Whether these competencies are developed during training, or represent dispositions that exist prior to training, it remains clear that the respondents highly valued these abilities in new student affairs professionals.

It is not surprising that administrative and management skills emerged as important to successful new professionals, for many past investigations have yielded similar results (i.e., Herdlein, 2004; Kretovics, 2002; Lovell \& Kosten, 2000; Newton \& Richardson, 1976; Ostroth, 1981). Additionally, some of the responsibilities identified by our respondents appeared administrative/management in nature (e.g., staff selection, writing reports, serving on department/university committees, developing and maintaining a budget), although these responsibilities were not strongly emphasized by the participants relative to direct student services. It appears contradictory that administra- 
tive/management responsibilities were not an area of emphasis for new professionals by our respondents, but the corresponding skills were an area of emphasis. Although new professionals may have a limited scope of professional responsibilities related to administrative/management functions, perhaps these competencies are necessary to implement the direct services, which are more reflective of their positions. For example, if student affairs professionals are to sustain programmatic efforts they must have the necessary administrative and management skills to support such efforts. These experiences may also be important for the professional development of new practitioners, because these entry-level responsibilities in the administration and management of direct student services may be an important training ground for advancement in higher education. Interestingly, Herdlein's (2004) study indicates graduate students were not well prepared for some student affairs administrative and management responsibilities (i.e., strategic planning, finance, budgeting), perhaps another indication that these early indirect experiences with administrative and management competencies are important for new professionals' development. Whether they are prepared to do so, it appears that new professionals may be expected to perform at a proficient level with regards to some administrative and management competencies.

Similar to the findings related to administrative and management skills, the finding that competency in computers and technology is important was not surprising. Technology has been widely discussed in postsecondary education, and ways of infusing technology in student affairs practice have been a topic of great interest (Barrett, 2003), although the importance of competency in technology for student affairs practice is a relatively new phenomenon (Lovell $\&$ Kosten, 2000). Additionally, the respondents did not emphasize job responsibilities in technology. Similar to administrative and management skills, however, competency in technology may underlie several important areas of student affairs practice. For example, it is expected that technology may serve as a foundation for some individual, group, and organizational interventions within student affairs. The most common example is the adoption of Web-based technologies, which allow students to take online courses, register for courses, and have access to their academic records. In addition, various departments may offer information or interventions through various forms of technology. For example, interactive career exploration groups have been offered as an 
online counseling intervention (Burkard \& Johll, 1999), and computer-assisted career exploration has been available for over 2 decades through the System of Interactive Guidance and Information (SIGI; Katz, 1993) and other such programs (e.g., DISCOVER). Additionally, computer-assisted and information technology have been used to assist in student recruitment (Johanson, 1993), career planning and placement (Noll \& Graves, 1998), and student advising (Treuer \& Belote, 1997). It appears that the integration of technology in postsecondary education and student affairs practice will continue to evolve, perhaps expanding student affairs practice in currently unforeseen ways. Although not recognized in the CAS (2003) standards for student affairs preparation programs, development of competency in technology will be essential for new student affairs professionals if they are to succeed in a world that increasingly embraces advances in technology.

Finally, it appears important that new professionals have some research competencies. Our respondents identified not only a specific competency in program evaluation, but also more general research competencies as important to successful entry-level practice. Here again, this finding may not be surprising, for competency in evaluation and research has been a point of emphasis in student affairs for some time (Upcraft \& Schuh, 1996), and it is among the recommended curriculum standards by CAS (2003). The importance of research competencies has been a consistent finding among past investigations (Herdlein, 2004; Kretovics, 2002; Lovell \& Kosten, 2000; Newton \& Richardson, 1976; Ostroth, 1981). Increasingly, practitioners are required to provide evidence for the efficacy of their services, often in written form (Upcraft \& Schuh, 1996). Relatedly, the respondents cited program evaluation as the one research responsibility important to entry-level student affairs practice. Although research may not be a major responsibility for new professionals, competency in research and program evaluation in particular is essential for moving toward evidence-based practice in student affairs (Schuh \& Upcraft, 2001; Upcraft \& Schuh, 1996).

\section{Theories}

Although this study was not an extensive investigation of knowledge fundamental to student affairs practice, theories that respondents considered important to successful professional practice were of interest. 
Perhaps not surprisingly, respondents identified several theories commonly acknowledged as reflective of student development and growth. For example, theories by Astin (1993), Chickering and Reisser (1993), Kohlberg (1984), and Perry (1981) were all identified as important for entry-level student affairs professionals' practice. These theories have been instrumental in helping many practitioners conceptualize and plan student services (McEwen, 2003), and based on these findings they will likely continue to be influential in the near future.

Additionally, the respondents also identified several diversity/multicultural based theories, such as women's development (Gilligan, 1982); racial identity development (Cross, 1971, 1995; Helms, 1995); minority identity developmental model (Atkinson, Morten, \& Sue, 1989); and lesbian, gay, \& and bisexual development (Cass, 1979; McCarn \& Fassinger, 1996). Diversity and multicultural issues, then, were the second most important collection of theories that respondents perceived to be important to the practice of entry-level professionals. These findings may be reflective of a growing recognition of cultural diversity on campus and the need to address specific issues, concerns, and interests of students who may be members of disenfranchised groups. Given that the respondents identified multicultural competency as an important skill area for new professionals, it certainly appears important to have the corresponding knowledge base. Clearly, the respondents perceived the importance of new professionals' knowledge of, and perhaps sensitivity to, culture and diversity issues in higher education.

\section{Implications for the Profession}

If these findings represent the expectations these mid- and senior-level student affairs may have of entry-level professionals, then these results have important implications for graduate preparation programs. Perhaps the most prominent implications of this study are those for curriculum development. Graduate preparation programs must examine the training offered in human relations, administration/management, technology, and research. The findings from this study offer some ideas regarding specific areas that programs may want to address. For example, graduate programs may want to include 
instruction on advanced counseling/human relation competencies (i.e., collaboration, consultation, group facilitation, conflict resolution/mediation, supervision, crisis intervention). Training in basic counseling helps new professionals intervene at the individual level, but these advanced competencies would help professionals intervene more effectively at the group and organizational level.

Additionally, it is important to acknowledge the diverse categories of skills new professionals are expected to acquire, which raises a question: How do programs adequately prepare new student affairs professionals? Interestingly, Herdlein (2004) addressed this important question and suggested increasing the number of credit hours or increasing the number of required course to meet such demands. Furthermore programs could consider areas of emphasis in graduate training, for these focal areas may have implications for competencies necessary for best practice in that area. For example, it may be essential that graduate students targeting careers in residence life have background training in more advanced counseling/human relations competencies; whereas, those students planning careers in admissions or financial aid may find an emphasis on technology or administration/management to be more useful to their career interests. Given the expanding expectations of entry-level professionals in student affairs, perhaps this is the time that training programs seriously consider the structure of current graduate curriculum.

Relatedly, graduate programs must begin to address the role of personal attributes and preprofessional skills in graduate training, for respondents clearly expressed the importance of such skills in new professionals' student affairs practice. Programs may want to assess how they currently address the development of students' personal attributes and preprofessional skills in their programs, and determine pedagogical methods that may be appropriate for assessing and teaching these skills. It is likely the development of these abilities would need to be infused throughout the graduate preparation program, although at least one author (Herdlein, 2004) has suggested considering the addition of a writing proficiency class to the curriculum. Perhaps these findings will encourage graduate faculty to consider innovative ways to address the development of these attributes and skills in their graduate programs. 
The specificity of the findings from this study may also have important implications for assessment of competencies of graduates. Given the maturation of the field of student affairs, increased pressure on professionals to work with technology and conduct research, and the expected qualifications for new professionals, the following question becomes important: How do we know that new professionals have acquired these expected competencies? Professional certification may likely be the next step and provide assurances that entry-level professionals have the minimum skills and competencies for entry into the field of student affairs. Exit evaluations specific to individual programs such as a thesis, comprehensive exam, or final paper may continue as useful graduate program requirements; but they are less effective for ensuring minimal skills and competencies expected for entry-level professionals. Instituting such national standards is not without their controversies, ranging from the types of measures used to cultural bias embedded in the certification process. Furthermore, instituting standardized assessments for entry-level professionals may reflect a lack of confidence in current practitioners and professional training programs. Additional inquiry and discussion in professional associations is required to determine whether standardized assessments are appropriate to ensure minimal qualification, and if certification is needed for practitioners and supervisors.

Finally, these results have important implications for the career planning for graduate students and new professionals, and they may serve as guidelines for professional development programs within student affairs. Graduate students and new professionals may want to use these findings to assess their current competencies and plan for the development of new skills. In such situations, graduate courses in other fields of study (e.g., counseling, business, computer science) or continuing education credits may be used to develop new skills to compliment those competencies already developed during graduate training. Those individuals who coordinate professional development activities in student affairs could use these results to guide the selection of workshops or other trainings to enhance the competencies of new professionals. 


\section{Limitations and Future Research}

The participants in this study were mid- and senior-level student affairs administrators who volunteered to participate in this study. These participants were also predominately from 4-year institutions. In particular, 2-year institutions were underrepresented in this study and account for only 4\% $(n=4)$ of the sample; whereas 96\% $(n=100)$ of the sample was comprised of 4-year private or public institutions. As such, the generalizability of the findings from this study to 2-year institutions may be limited. It is also possible that some respondent characteristics may have influenced the results, as may have the return rate of $35 \%$. Relatedly, some characteristics of the institution may have also influenced the final results. For example, we did not assess whether respondents were from historically Black colleges/universities or other predominantly minority-serving institutions. It may be the identified competencies would have been different in these institutions.

Given these limitations and the present findings, then, results from this study have some important implications for future research. First, future researchers may want to examine if the results from this study generalize to other types of institutions, particularly 2-year institutions. For example, it is entirely conceivable that new professionals at 2-year institutions may have a greater breadth of responsibilities, thus requiring greater breadth of competencies, in comparison to those professionals at larger institutions. Additionally, historically Black colleges/universities or other predominantly minority-serving institutions may deem some competencies (e.g., multicultural competencies) as more important than predominately White institutions. Second, given the breadth of competencies that our respondents identified as important to new professionals, it may be important to understand how well prepared graduate students are to perform such activities. The results of such research may better guide graduate curriculum assessment and redesign, and provide information that may be useful in such efforts. Finally, the salience of personal attributes and preprofessional skills identified by the respondents in this study are striking. It may be important to understand the relationship to or the role that these abilities have in professional development. In particular, future researchers may want to understand if these skills represent areas of deficit or strength for new professionals. 


\section{Conclusion}

This study developed consensus among mid- and senior-level professionals regarding the responsibilities, skills, and theoretical knowledge bases of entry-level professionals in student affairs. Though some might describe student affairs as the "housekeeper of academe," students' personal and intellectual growth is among the professions' highest goals (McEwen, 2003). Student affairs, particularly entry-level professionals, expect to be involved with and provide services to individual and groups of students on a daily basis. As such, the collegiate experience without student affairs services likely ceases to be little more than an institute for professional training. The preparation of student affairs professionals must continue to provide strong training in human relation (including multicultural competencies) and management skills, for these abilities appear to be foundations of practice. However, graduate programs should also address the growing needs in advanced technology and research, especially program evaluation. As computer-based technologies become more integrated into our campuses, professionals will be required to have increased familiarity and experience with various technological tools. While the expansion of technology requires additional training for new professionals, the financial constraints of institutions will require student affairs professionals to demonstrate their worth and value to their students and larger campus community. Although models of student affairs competencies assume the development of particular skills, competencies, and knowledge bases within training programs, the findings in this study have identified specific competencies important to student affairs practice in the changing dynamics of higher education institutions.

\section{References}

Ascher, W. (1978). Forecasting. Baltimore: John Hopkins University Press.

Astin, A. W. (1993). What matters in college? Four critical years revisited. San Francisco: Jossey-Bass.

Atkinson, D. R., Morten, G., \& Sue, D. W. (1989). A minority identity development model. In D. R. Atkinson, G. Morten, \& D. W. Sue (Eds.), Counseling American Minorities (pp. 35-52). Dubuque, IA: W. C. Brown. 
Baier, J. L. (1992). A study of student affairs functions and administrative responsibilities within university system offices. NASPA Journal, 29, 189-198.

Barrett, W. (2003). Information technology in student affairs. In S. R. Komives, \& D. B. Woodard, Jr. (Eds.), Student services: A handbook for the profession (4th ed., pp. 379-396). San Francisco: Jossey-Bass.

Beatty, D. L., \& Stamatakos, L. C. (1990). Faculty and administrator perceptions of knowledge, skills, and competencies as standards for doctoral preparation programs in student affairs administration. Journal of College Student Development, 31, 221-229.

Bureau of Labor Statistics. (2004). Occupational Employment and Wages, May 2003. April 21, 2005, from http://www.bls.gov/news. release/archives/ocwage_04302004.pdf.

Burkard, A. W., \& Johll, M. J. (1999, January). Facilitating career exploration through electronic mail groups. Paper presented at the annual meeting for the National Consultation on Career Development Conference, Ottawa, Canada.

Cass, V. C. (1979). Homosexual identity formation: A theoretical model. Journal of Homosexuality, 4, 219-235.

Chickering, A. W., \& Reisser, L. (1993). Education and identity (2nd ed). San Francisco: Jossey-Bass.

Council for the Advancement of Standards in Higher Education. (2003). The book of professional standards for higher education. Washington, DC: Author.

Cross, W. E. (1971). The negro-to-black conversion experience: Toward a psychology of black liberation. Black World, 20, 13-27.

Cross, W. E. (1995). The psychology of Nigrescence: Revising the Cross model. In J. G. Ponterotto, J. M. Casas, L. A. Suzuki, \& C. M. Alexander (Eds.), Handbook of multicultural counseling (pp. 93-122). Thousand Oaks, CA: Sage.

Dalkey, N. (1969). Experimental study of group opinion. Futures, 1, 408-426.

El-Khawas, E. (2003). The many dimensions of student diversity. In S. R. Komives \& D. B. Woodard, Jr. (Eds.), Student services: A handbook for the profession (4th ed., pp. 45-62). San Francisco: Jossey-Bass.

Erikson, E. (1968). Identity: Youth and crisis. New York: Norton.

Fish, L. S., \& Busby, D. M. (1996). The Delphi method. In D. H. Sprenkle (Ed.), Research methods in family therapy. New York: Guilford Press. 
Fried, J. (2003). Ethical standards and principles. In S. R. Komives \& D. B. Woodard, Jr. (Eds.), Student services: A handbook for the profession (4th ed., pp. 107-127). San Francisco: Jossey-Bass.

Gilligan, C. (1982). In a different voice. Cambridge, MA: Harvard University Press.

Gordon, S. E., Strode, C. B., \& Mann, B. A. (1993). The mid-manager in student affairs: What are CSAOs looking for? NASPA Journal, 30, 290-297.

Helms, J. E. (1995). An update of Helms's white and people of color model racial identity models. In J. G. Ponterotto, J. M. Casas, L. A. Suzuki, \& C. M. Alexander (Eds.), Handbook of multicultural counseling (pp. 181-198). Thousand Oaks, CA: Sage.

Herdlein, R. J. (2004). Survey of chief student affairs officers regarding relevance of graduate preparation of new professionals. NASPA Journal, 42, 51-71.

Johanson, W. F. W. (1993). The electronic advantage: High-tech applications (and more) in student recruitment. Currents, 19, 46-49.

Jones, L., Castellanos, J., \& Cole, D. (2002). Examining the ethnic/minority student experience at predominantly white institutions: A case study. Journal of Hispanic Higher Education, 1, 19-39.

Katz, M. R. (1993). Computer-assisted career decision making: The guide in the machine. Hillsdale, NJ: Lawrence Erlbaum.

Kohlberg, L. (1984). The psychology of moral development: The nature and validity of moral stages. San Francisco: Harper \& Row.

Kretovics, M. (2002). Entry level competencies: What student affairs administrators consider when screening candidates. Journal of Student Development, 43, 912-920.

Linstone, H. A., \& Turoff, M. (Eds.). (1975). The Delphi method: Techniques and applications. Reading, MA: Addison Wesley.

Lovell, C., \& Kosten, L. (2000). Skills, knowledge, and personal traits necessary for success as student affairs administrator: A metaanalysis of thirty years of research. NASPA Journal, 37, 553-572.

Lunsford, L. W. (1984). Chief student affairs officer: The ladder to the top. NASPA Journal, 22, 48-56.

Maslow, A. H. (1968). Toward a psychology of being. Princeton: Van Nostrand.

McCarn, S. R., \& Fassinger, R. E. (1996). Revisioning sexual minority identity formation: A new model of lesbian identity and its implications for counseling and research. The Counseling Psychologist, $24,508-534$. 
McEwen, M. K. (2003) The nature and uses of theory. In S. R. Komives \& D. B. Woodard (Eds.), Student services: A handbook for the profession (4th ed., pp. 153-178). San Francisco: Jossey-Bass.

Miles, M. B., \& Huberman, A. M. (1994). Qualitative data analysis: An expanded sourcebook (2nd ed.). Thousand Oaks, CA: Sage.

Newton, F. B., \& Richardson, R. L. (1976). Expected entry-level competencies of student personnel workers. Journal of College Student Personnel, 17, 426-430.

Noll, C. L, \& Graves, P. R. (1998). Technology and educational support offered by university career centers. Journal of Career Planning and Employment, 58, 20-24.

Ostroth, D. D. (1981). Competencies for entry-level professionals: What do employers look for when hiring new staff? Journal of College Student Personnel, 22, 5-11.

Perry, W. G. (1981). Cognitive and ethical growth: The making of meaning. In A.W. Chickering (Ed.), The modern American college: Responding to the new realities of diverse students and a changing society (pp. 76-116). San Francisco: Jossey-Bass.

Pope, R. L., \& Reynolds, A. L. (1997). Student affairs core competencies: Integrating multicultural awareness, knowledge, and skills. Journal of College Student Development, 38, 266-277.

Schuh, J. H., \& Upcraft, M. L. (2001). Assessment in student affairs: An applications manual. San Francisco: Jossey-Bass.

Strauss, A., \& Corbin., J. (1990). Basics of qualitative research: Grounded theory procedures and techniques. Newbury Park, CA: Sage.

Talbot, D. M. (2003). Multiculturalism. In S. R. Komives \& D. B. Woodard, Jr. (Eds.), Student services: A handbook for the profession (4th ed., pp. 423-446). San Francisco: Jossey-Bass.

Treuer, P., \& Belote, L. (1997). Current and emerging applications of technology to promote student involvement and learning. New Directions for Student Services, 78, 17-30.

Upcraft, M. L. (2003). Assessment and evaluation. In S. R. Komives \& D. B. Woodard, Jr. (Eds.), Student services: A handbook for the profession (4th ed., pp. 555-572). San Francisco: Jossey-Bass.

Upcraft, M. L, \& Schuh, J. H. (1996). Assessment in student affairs: A guide for practitioners. San Francisco: Jossey-Bass. 